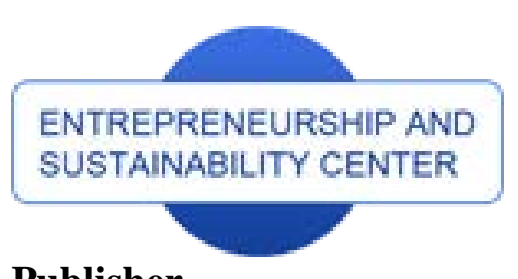

Publisher

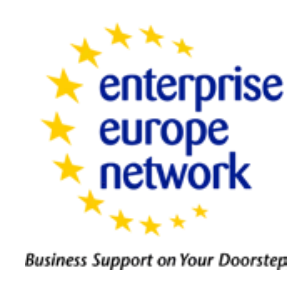

THOMSON REUTERS

Emerging Sources Citation Index WEB OF SCIENCE'M

\title{
ECOSYSTEM OF ENTREPRENEURSHIP: RISKS RELATED TO LOSS OF TRUST IN STABILITY OF ECONOMIC ENVIRONMENT IN KAZAKHSTAN
}

\author{
Elena Petrenko ${ }^{1}$, Nurlan Iskakov ${ }^{2}$, Oleg Metsyk ${ }^{3}$, Tatyana Khassanova ${ }^{4}$ \\ ${ }^{1,4}$ Department of Marketing Communications Institute of Economics, Trade and Technology, South Ural University, \\ Lenina str. 76, Chelyabinsk, 454080, Russia \\ ${ }^{2}$ Almaty Management University Rosybakieva str. 227, Almaty 050060, Kazakhstan \\ ${ }^{3}$ Ural branch of RAS of The Institute of Economics at the Russian Academy of Sciences, \\ (Ural branch) Moskovskaya str. 29, Yekaterinburg 620014, Russia \\ E-mails: 1petrenko_yelena@bk.ru, ${ }^{2}$ cmtis@mcudp.kz, ${ }^{3}$ omezik@inbox.ru,_tatiana_hasanova@mail.ru
}

Received 27 March 2017; accepted 20 July 2017

\begin{abstract}
Favorable ecosystem of entrepreneurship plays crucial role for successful development of small and medium enterprises (SMEs) and their sustainability. One of preconditioms of encouraging business environment is its' stability, and trust in long-term stability. Meanwhile the global economic crisis has created a state of economic and political instability, what consequently affected trust of business entities, and therefore contributed to increase of social and economic risks. The article discusses the decline of trust in the entrepreneurship of Kazakhstan, examines the causes and consequences of loss of confidence as an important institutional resource.
\end{abstract}

Keywords: entrepreneurship ecosystem, trust, business risks, economics, Kazakhstan, SMEs, corruption, state

Reference to this paper should be made as follows: Petrenko, E., Iskakov, N., Metsyk, O.; Khassanova, T. 2017. Ecosystem of entrepreneurship: risks related to loss of trust in stability of economic environment in Kazakhstan, Entrepreneurship and Sustainability Issues 5(1): 105-115. http://doi.org/10.9770/jesi.2017.5.1(8)

JEL Classifications: O15, O5, O53; P4; P47

\section{Introduction}

Economic and social safety of the republic depends on a condition and development of small and medium business in the current conditions of economic instability and geopolitical turbulence in which Kazakhstan is involved. Mobility and flexibility of small and medium business allows to smooth negative consequences of crisis in which there were extracting republic industries. The domestic entrepreneurship absorbs the released labor power, provides social adaptation, and creates new market niches and points of economic growth.

The conditions of a business environment, or ecosystem of entrepreneurship, is a key factor of economic safety of the state. Business climate estimates a level of credibility as economic and social category. Therefore various 
facets of entrepreneurship ecosystem is widely discussed in scientific literature (e.g. Štitilis et al 2016; Tvaronavičienè et al. 2016; Laužikas et al. 2015; Sun, Fuschi 2015; Grubicka, Matuska 2015; Tumalavičius et al. 2017; Gavurova et al. 2017; Bilan et al. 2017; Rajnoha, Lesníková, 2016).

Kazakhstan on the commonly accepted practice carries out monitoring of the entrepreneurial environment for determination of priorities of policy in the field of development and support of subjects of small and medium entrepreneurship. Authors of the article suggest to consider business environment by putting especial emphasis on risks of instability and decrease in social and economic safety of the country.

The world community has faced loss of understanding of a global trajectory of development of economy. The processes proceeding in various markets and in regions are characterized by such level of instability and turbulence that it is possible to speak about loss of basic model of the economic relations. Creation of a new order and new model is prevented by not deficit of theoretical designs, but by loss of one of the main criteria of mutual understanding and trust.

The phenomenon of trust is a basis practically of all economic and social processes, and therefore various implications of this factors is widely discussed both in classic (e.g. Williamson 1993; Barney, Hansen 1994; Gulati 1995; Fukuyama 2004) and contemporary literature (Sultan et al. 2002; Guo et al. 2017; Tang et al. 2017; Park et al. 2017; Yonk et al. 2017; McKnight et al. 2017; Rego et al. 2017; Zaefarian et al. 2017; Kim et al. 2017; Fiedler et al. 2017; Meqdadi et al. 2017; Valentim et al. 2017).

In fact the main problem - whether world (any) economy will be able to win at a scale having reduced at the same time transactional expenses. Certain mechanisms are urged to reduce these expenses, but availability of a necessary and sufficient level of credibility is always the cornerstone of their functioning. The trust is also a factor of fight against asymmetry of information between agents. Prevalence of "mistrust in society is equivalent to entering of the additional tax on all forms of economic activities of which societies with a high income level are relieved” (Fukuyama 2004, p.55).

\section{Methodology}

Authors determine that trust as fundamental economic category without which the market relations is impossible. At the same time the trust cannot be created artificially, it is result of influence of social and economic conditions. In modern society "the trust radius" is narrowed - a circle of people and the social groups entering into single system of trusting relationships. F.Fukuyama notes that any society possesses a certain inventory of a social capital, considerable distinctions between them are caused by the radius of trust (Fukuyama 2004). A task of article authors' is to asses risks of the Kazakhstan economy caused by reducing radius of trust. 

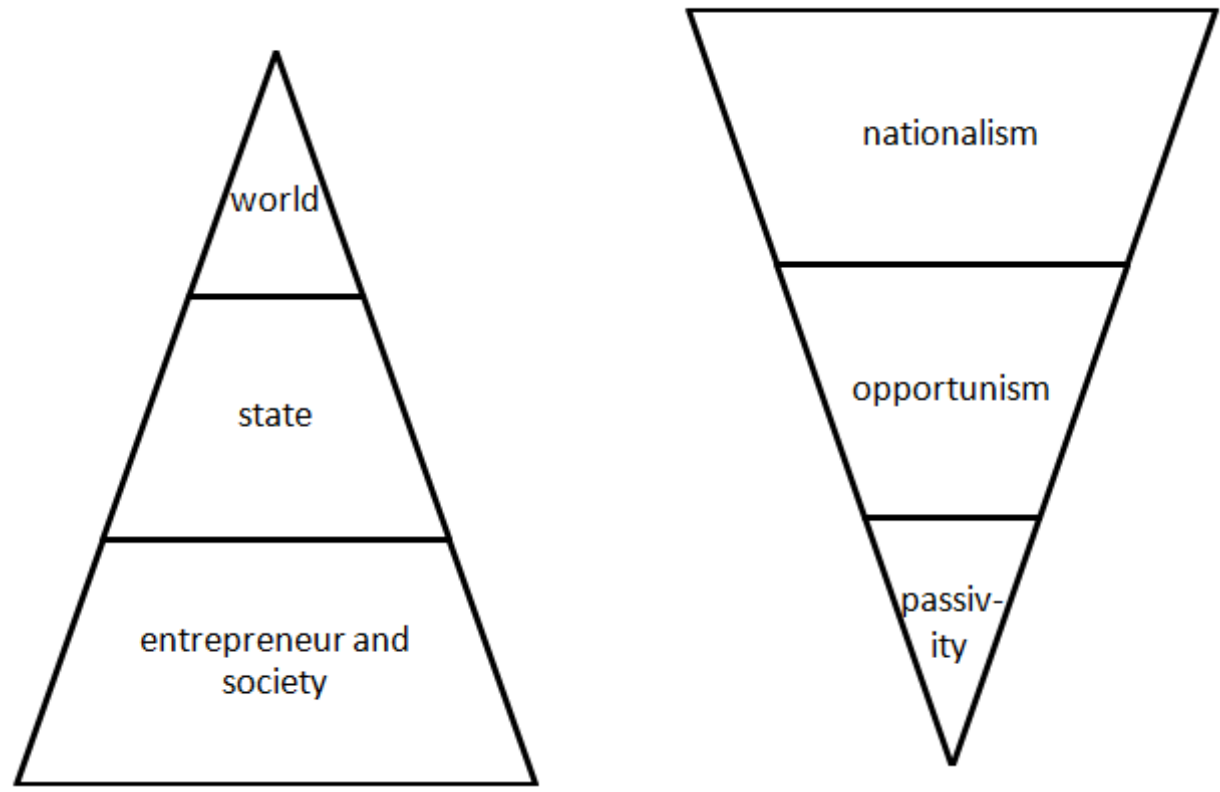

Figure 1. Levels of trust and risks

Authors consider trust as the institutional economic category determining behavior of the economic actors in system of economic activity of various levels (Fig. 1). Certain content of concept "Trust" included in a wide value system and determining behavior of the subject at the hierarchical level corresponds to each level of globalization of economic systems. Depending on the level of hierarchy increases importance of trust as basic category and increases danger of level of loss. Loss of trust of the top level can lead to strengthening of trust of basic levels, however, can be followed also by crash of all valuable and confidential system of relations in entrepreneurship.

Basic level of values for the entrepreneur, as well as any person, am its own "I" and the society surrounding it the family, relatives, friends. The level of trust shall be maximum here. Even the slightest loss of trust to itself leads to destruction of the person as persons, reduces his social activity. For entrepreneurship as special type of activity, the availability of a personal initiative based on confidence in own opportunities - is the dominating factor. Trust to the entrepreneur - the first and most important investment into business, especially in small. A family support, an inner circle and compatriots - important levels of ensuring trust which importance weakens in process of removal from the entrepreneur.

Loss of trust of the first basic level creates threat of apathy, failure act of the specific entrepreneur. In case of mass manifestation of loss of trust at a basic level there is a danger of reducing entrepreneurship as bases of forming of market society. The level of trust to the state and its institutes creates loyalty of economic behavior of entrepreneurs. In case of decrease in trust to the state business begins to pass from legal to shadow forms of economy, to show economic and political opportunism and to support criminal schemes of economic behavior. However business can continue at the expense of a support on own resources and the immediate environment. The trust to the outside world creates readiness to take part in processes of the international level. The entrepreneurial communities trusting to foreign countries and associations are open to innovations, do business, invest the capitals out of the country and the region. Loss of trust to an external environment, recognition of his 
hostility leads to isolation of country business, origin of nationalism. Mistrust of domestic business to processes of world integration creates self-isolation threats. During a certain period it can lead to growth of local business, but in the strategic period the isolated development reduces competitiveness of regions and countries. The Kazakhstan economy is now in the difficult economic period which duration generates new threats and risks. According to authors, noted negative tendencies of the Kazakhstan entrepreneurship have system character and the greatest problem is the loss of trust creating destructive business models. In the provided article is considered the interrelation of problems of development of the Kazakhstan business with loss of entrepreneurial trust and generation of threats of economic safety of the country.

\section{Analysis}

Empiric basis of the article is made of researches conducted by the National Chamber of Entrepreneurs that were published in the National report on entrepreneurship activity condition, Doing Business in Kazakhstan 2017 (National report on entrepreneurship activity condition, Doing Business in Kazakhstan 2017). The bureaucracy, corruption and big terms of consideration of documents constitute three main barriers to effective interaction of the state and business according to National Chamber of Entrepreneurs.

The first part of article is devoted to studying of major factors of interrelation of loss of trust and emergence of threats of the Kazakhstan entrepreneurship.

The bureaucracy and corruption as the most dangerous and system threats will be considered in separate, second part of the publication.

Bureaucracy, corruption and long term of documents processing are three main barriers for effective statebusiness interaction. The article is dedicated to studying main factors of correlation between losses of trust and forming of threats to Kazakhstani entrepreneurship. Ecosystem of entrepreneurship of business in Kazakhstan is in a difficult state. Kazakhstan made it up to the $35^{\text {th }}$ place in the rating Doing Business-2017 that is annually issued by one of the departments of the World Bank from the $41^{\text {st }}$ place in 2015. By global comparison, Doing Business remains procedurally complex across Kazakhstan, in all areas measured except registering property (Fig. 2). 


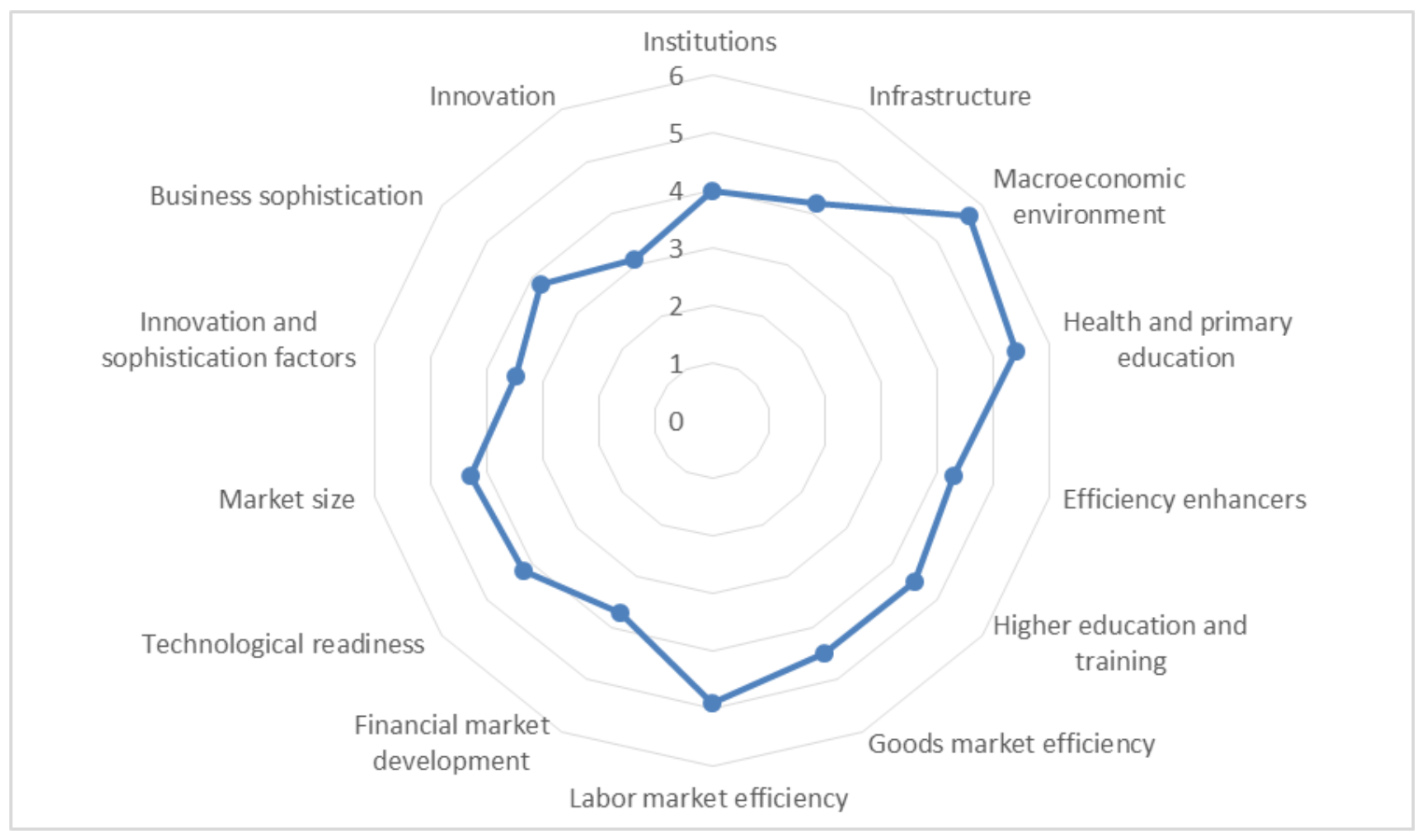

Figure 2. Global Competitiveness Index.

Source: Doing Business in Kazakhstan (2017)

Doing Business in Kazakhstan 2017 is the first report of the subnational Doing Business series in Kazakhstan. It measures business regulations and their enforcement in four Doing Business areas. It goes beyond Almaty city to benchmark seven additional Kazakhstani locations-Aktobe, Astana, East Kazakhstan (Oskemen), Karagandy, Kostanay, Pavlodar and South Kazakhstan (Shymkent). This report's regional data is current as of December 2016 and includes comparisons with Almaty city and other economies based on data from Doing Business 2017: Equal Opportunity for All, the 14th in a series of annual reports published by the World Bank Group. The indicators in Doing Business in Kazakhstan 2017 are also comparable with more than 400 locations from 65 economies benchmarked in other subnational Doing Business studies (National report on entrepreneurship activity condition).

By Doing Business in Kazakhstan 2017 the most problematic factors for doing business are: corruption, access to financing, inefficient government bureaucracy, tax regulations, inadequate supply of infrastructure, inflation inadequately educated workforce, insufficient capacity to innovate, tax rates foreign currency regulations crime and theft, restrictive labor regulations, poor work ethic in national labor force, government instability/coups. The National report on entrepreneurship activity condition underlines and rates five key factors of entrepreneurship development in 4 rate scale. These factors are: administrative regulation, real estate and infrastructure, human resources, financial resources and state support (Fig. 3). 


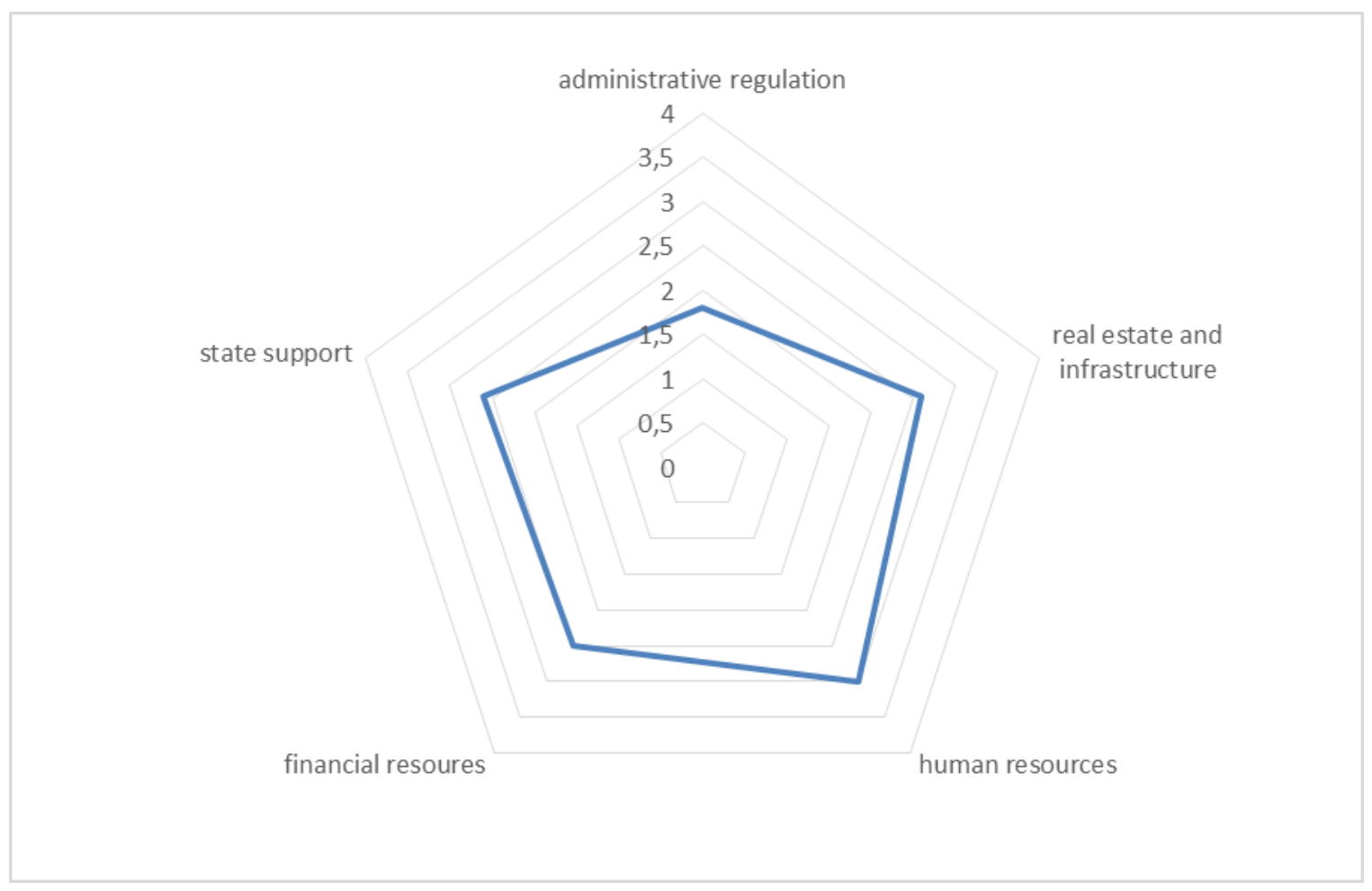

Figure 3. Business conditions in Kazakhstan

Source: Done by the author, based on the materials of the National report (2017)

The survey of 4600 entrepreneurs showed that the biggest problems and risks in entrepreneurship are provoked by administrative regulation. Annual research Business climate in 2016 makes the evaluation of business situation in Kazakhstan based on the survey of 4107 respondents, $47 \%$ of which were small business, $45 \%$ were middle business and 8\% were agriculture( Business Climate, 2016). The biggest problems for the respondents were long terms of documents processing (15\%) as well uncompetent civil servants (15\%), in common bureaucratic consideration of the documents makes $30 \%$ of the score.

State support programs do not perform planned effect. State program “Business Road Map-2020” provides involvement of only 12\% of informed audience (Business Climate, 2016). Citizens of the country evaluate the ability to do their own business as low. Only $15 \%$ of population are ready to consider the possibility to become entrepreneurs that first of all is due to the high barriers to business activity in the country. As a result the share of the entrepreneurs "out of necessity" who have to do business as they do not have any other income is $26,4 \%$. (National report on entrepreneurship activity condition, 2017).

Authors have revealed ten most burning issues of development of the Kazakhstan entrepreneurship on the basis of the analysis of the current situation:

- lack of interest in business activity;

- a dissatisfaction with business conditions in the country;

- dependence on informal communications;

- not innovation of entrepreneurship;

- low professional competence of entrepreneurs;

- conservatism of business; 
- low competitiveness of domestic entrepreneurship;

- fear of financial instability;

- corruption;

- shadow economy.

Interrelation of loss of trust and emergence of threats of the Kazakhstan entrepreneurship is provided in Figure 4.

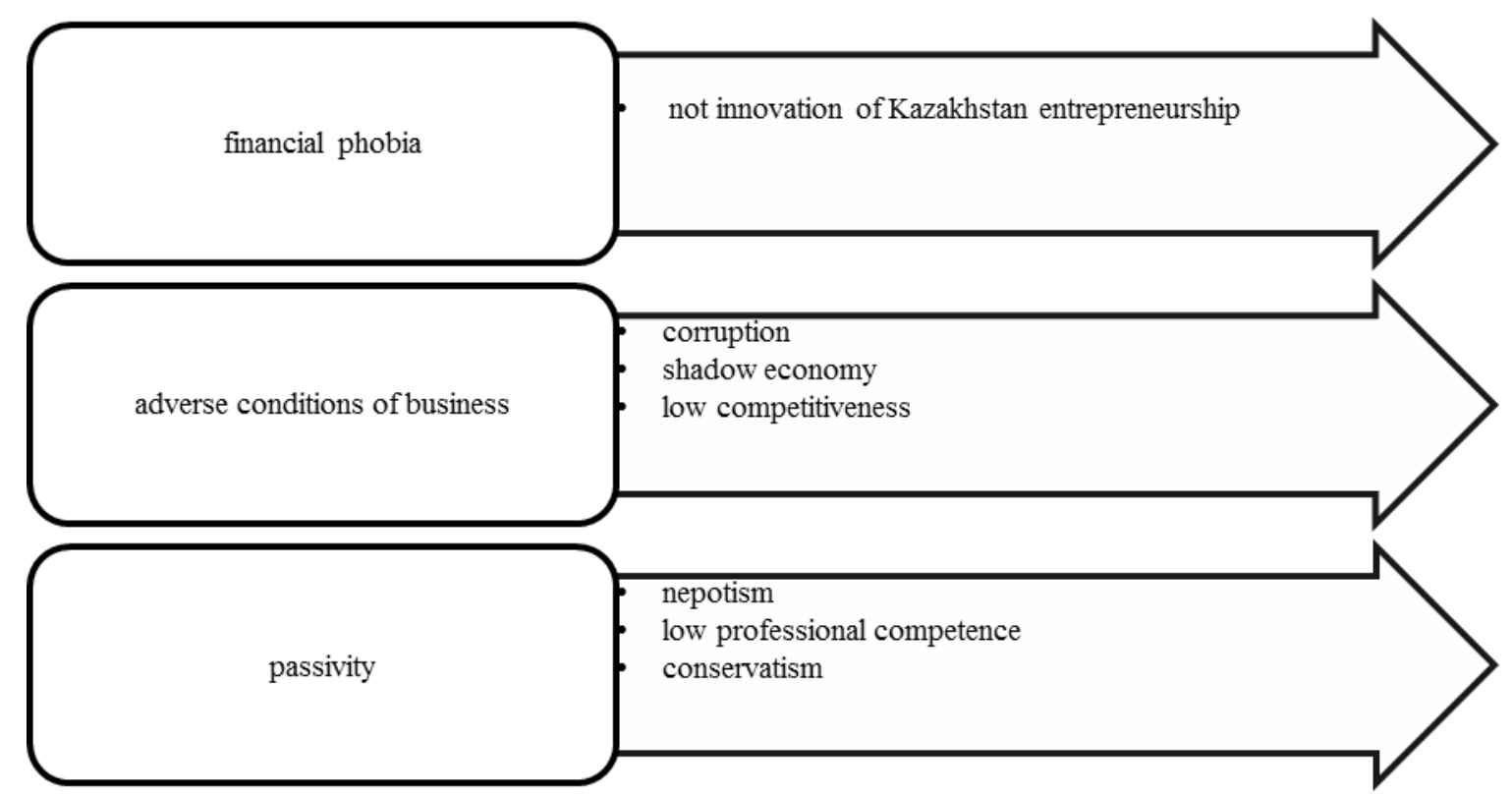

Figure 4. Interrelation of loss of trust and emergence of threats of the Kazakhstan entrepreneurship

1. The brightest loss of trust as economic category is shown in loss of trust of entrepreneurs to a domestic financial system. According to National bank of Kazakhstan deposits of physical persons and legal entities in foreign currency constituted 70\% from the total amount of deposits. Mistrust to a domestic financial system in Kazakhstan develops into a steady phobia and generates fear of innovations. Instability and uncontrollability of a rate of tenge makes impossible planning of investments in national currency and creates the steady pattern of entrepreneurial behavior avoiding innovations as uncontrollable costs.Out of 4107 respondents of the survey Business Climate $45 \%$ of the entrepreneurs have difficulties with getting bank loans, at the same time $15 \%$ of the entrepreneurs say about great difficulties in obtaining bank loan( National Bank of Kazakhstan,2016). Innovations in business management and production processes are implemented by only one third of entrepreneurs. It should be noted that domestic entrepreneurs do not differ in innovation not only at the practical level, but even at the level of intentions and a plan. Innovative technologies choose no more than 2 entrepreneurs from 10 . These results confirm low mental competitiveness of the Kazakhstan entrepreneurs. It is noted not only low actual innovation, but also low level of understanding of a subject of an innovation that enters it and as to develop it. At the same time in the conditions of global fight for the market and the client the competition cannot sustain without implementation of innovations in the production technology and business. Low innovation of the Kazakhstan business creates risks of loss of the international competitiveness and creates losses of the international economic safety. 
2. Adverse conditions for business undermine confidence of entrepreneurs to the commitment to the market relations declared by the state and democracy. Only one third of the interrogated respondents considers that in Kazakhstan are created favorable conditions to start the business. This indicator reflects a low level of trust to the entrepreneurial environment as parts of country community. The youth of Kazakhstan has no desire to become entrepreneurs, the main contingent of potential entrepreneurs constitutes the population about 40 years. By estimates of authors, the desire to be engaged in business is stated by about $15 \%$ of youth. Loss of trust to the state support of business gives rise to three types of risk: low competitiveness of domestic business, leaving of entrepreneurship in a shadow economy and corruption. Corruption and a shadow economy are the most dangerous systemic risks for economy of Kazakhstan. Their manifestation, development and consequences will be researched separately in the second part of our article. We will consider risk of low competitiveness of the Kazakhstan entrepreneurship as generation of mistrust to a possibility of business development. The policy of support of business realized by the state stimulates only about $2 \%$ of respondents. Entrepreneurship lack of work in the labor market is a basic reason of occupation. The entrepreneurship realized not as the personal initiative and the voluntary choice, and as uncontested employment bears in themselves stability threat. Such entities initially are characterized by low competitiveness and profitability of business, and also high level of volatility to external risks and instability. The Kazakhstan entrepreneurship develops in regions where there is rather strong enterprising competition, big density of population that allows to expect to entrepreneurs the market in the region. This phenomenon confutes a hypothesis according to which, potential entrepreneurs appear in regions with the low competition, according to great opportunities for entry into the market. This tendency increases distinction between the backward and developed regions of the country and creates threat of internal instability.

Kazakhstan as the state living on a raw rent and disposing of the main part of the income from exploitation of natural resources is the chief employer and does not stimulate business activity. Annual average number occupied in Kazakhstan has constituted 8,5 million people, from them:

-39 the \% occupied at the entities of a private sector;

$-28 \%$ employees of the entities with state participation;

$-4 \%$ employees of overseas enterprises;

$-28 \%$ self-employed workers.

The state spheres - education, health care and a state administration - have provided the main contribution to an employment surplus since 2010. The private sector practically does not generate creation of new fixed workplaces in recent years. The work market situation in 2016 will depend in many respects on actions of the state and quasipublic sectors which, in addition to direct employment, provide a considerable share of demand for products made in the country.

3. Entrepreneurial passivity as reaction to domination of the state in economy, is the most important institutional sign of loss of trust of citizens to the declaration of economic equality and independence of each subject. Characteristic of business in Kazakhstan is its related focus. Without trusting the state as to the partner, the entrepreneur limits trust to a circle of the next society. For the organization and development of own business Kazakhstan citizens are guided by resources of the family and relatives. The nepotism as basic social model constitutes threat of development not only business, but also all management system and is the cornerstone of the Kazakhstan model of corruption. The Kazakhstan owners of business in the choice of entrepreneurship as main activity are guided first of all by desire of finding of independence (41,4\%), including financial (16\%). At the same time availability of necessary knowledge and skills in implementable activities mark out about $16 \%$ of respondents. Incompetence is one of the main risks of the Kazakhstan entrepreneurship. It is directly connected with risk of a nepotism as business models and as a result generates the most dangerous forms of corruption about 
what it will be in detail researched in the second part of article. Creation of the strong, competent organizations in the future is under the threat because of low competence entering small business. Only 1\% of potential entrepreneurs have necessary skills of competitiveness: knowledge of the case, absence of fear, ability to plan. Considering that the Kazakhstan entrepreneurs concentrate business in the developed, competitive markets, they do not plan creation of offers of new goods or services, thereby creations of a new niche for the activities. Commitment to implementation of traditional types of activity which will bring in certain stable incomes; amplifies high average age of the beginning entrepreneurs, not persons interested to create new goods and services. Conservatism creates threat of stagnation of a business sector and decrease economic safety of the country.

\section{Conclusions}

The trust becomes a contempory problem. The modern situation is characterized by high degree of uncertainty. Preserving economic activity is a question of the attitude of entrepreneurs towards the increasing risks. The market system does not work without expectation of accomplishment of liabilities and trust to reliability of partners. All participants of the market relations in the conditions of dynamically changing external environment and high instability of the financial markets shall make economic decisions quickly. Level of instability of the world market and, the market of Kazakhstan as its parts, creates a situation in which the most part of information does not give in to sure forecasting. In these conditions decision making process is based on trust. The market as system of economic and social exchanges requires basic trust to the system of institutes. Without it the exchange will not be general. In Kazakhstan is broken generality of trust and systems of business entrepreneurial activity. Loss of trust, deficit of trust does not give the chance of long-term planning, promotes increase of institutional barriers, inevitably increases uncertainty and instability of the institutional environment, all this does the existing institutes are inefficient. And without effective institutes those purposes which are set before the Kazakhstan economy — upgrade, innovations, sustainable economic development are impossible.

\section{References}

Azamatova, R.; Shadova, Z.; Shorova, B. (2017). Economic security and international relations in the European Union, Journal of Security and Sustainability Issues 6(4): 711-718. http://doi.org/10.9770/jssi.2017.6.4(15)

Barney J. B.; Hansen M.H. (1994). Trustworthiness as a source of competitive advantage, Strategic Management Journal, Vol. 15 http://doi.org/10.1002/smj.4250150912

Bilan, Y.; Mishchuk, H.; Pylypchuk, R. (2017). Towards sustainable economic development via social entrepreneurship, Journal of Security and Sustainability Issues 6(4): 691-702. http://doi.org/10.9770/jssi.2017.6.4(13)

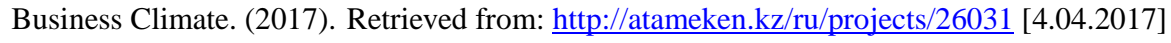

Commitee of Statitics. (2017). Retrieved from: http://stat.gov.kz [7.06.2017]

Doing Business in Kazakhstan. (2017). Retrieved from: http://doingbusiness.gov.kz/ [21.05.2017]

Doing Business in Kazakhstan. (2017). Retrieved from: www.doingbusiness.org/reports/subnational-reports [5.06.2017]

Fiedler, Antje; Fath, Benjamin P.; Whittaker, D. Hugh. (2017). Overcoming the liability of outsidership in institutional voids: Trust, emerging goals, and learning about opportunities, , International Small Business Journal 35(3): 262-284 Published: MAY 2017 https://doi.org/10.1177/0266242616662510 
Fukuyama F. (2004). Trust: social virtues and the path to prosperity, OOO "Publishing house ACT": ZAO NPP "Ermak", 2004.730 S.

Gavurova, B.; Virglerova, Z.; Janke, F. (2017). Trust and a sustainability of the macroeconomic growth insights from dynamic perspective, Journal of Security and Sustainability Issues 6(4): 637-648. http://doi.org/http://doi.org/10.9770/jssi.2017.6.4(9)

Grubicka, J.; Matuska, E. (2015). Sustainable entrepreneurship in conditions of UN (Safety) and technological convergence, Entrepreneurship and Sustainability Issues 2(4): 188-197. http://doi.org/10.9770/jesi.2015.2.4(2)

Gulati R. (1995). Does familiarity breed trust \& the implications of repeated ties on contractual choice in alliances, Academy of management journal 38(1): 85-112 http://www.hbs.edu/faculty/Pages/item.aspx?num=30984

Guo, Wenbo; Feng, Jing Betty; McKenna, Brad; et al. (2017). Inter-organizational governance and trilateral trust building: a case study of crowdsourcing-based open innovation in China, Asian Business \& Management_ 16 (3): 187-207 Published: JUL 2017 http://doi.org/10.1057/s41291-017-0019-1

Kim, Yeolib; Peterson, Robert A. (2017). A meta-analysis of online trust relationships in E-commerce, Journal of Interactive Marketing 38: 44-54 Published: MAY 2017 https://doi.org/10.1016/j.intmar.2017.01.001

Laužikas, M.; Tindale, H.; Bilota, A.; Bielousovaitè, D. (2015). Contributions of sustainable start-up ecosystem to dynamics of start-up companies: the case of Lithuania, Entrepreneurship and Sustainability Issues 3(1): 8-24. http://doi.org/10.9770/jesi.2015.3.1(1)

McKnight, D. Harrison; Lankton, Nancy K.; Nicolaou, Andreas; et al. (2017). Distinguishing the effects of B2B information quality, system quality, and service outcome quality on trust and distrust, Journal Of Strategic Information Systems 26 (2): 118-141 Published: Jun 2017 https://doi.org/10.1016/j.jsis.2017.01.001

Meqdadi, Osama; Johnsen, Thomas E.; Johnsen, Rhona E. (2017). The role of power and trust in spreading sustainability initiatives across supply networks: A case study in the bio-chemical industry, Industrial Marketing Management 62: 61-76 Published: APR 2017 http://doi.org/10.1016/j.indmarman.2016.06.006

National Bank of Kazakhsta. (2016). Retrieved from: http://www.nationalbank.kz

National report on entrepreneurship activity condition. (2017).

http://atameken.kz/uploads/content/files/Текст\%20Национального\%20доклада \%20обновлен.pdf

Park, Eunil; Kim, Ki Joon; Kwon, Sang Jib. (2017). Corporate social responsibility as a determinant of consumer loyalty: an examination of ethical standard, satisfaction, and trust, Journal Of Business Research 76: 8-13. http://doi.org/10.1016/j.jbusres.2017.02.017

Rajnoha, R., Lesníková, P. (2016). Strategic Performance Management System and Corporate Sustainability Concept - Specific Parametres in Slovak Enterprises, Journal of Competitiveness 8(3): 107 - 124. http://doi.org./10.7441/joc.2016.03.07

Rego, Armenio; Pina e Cunha, Miguel; Polonia, Daniel. (2017). Corporate Sustainability: a view from the top, Journal of Business Ethics 143 (1): 133-157 Published: JUN 2017

Štitilis, D.; Pakutinskas, P.; Malinauskaitè, I. (2016). Preconditions of sustainable ecosystem: cyber security policy and strategies, Entrepreneurship and Sustainability Issues 4(2): 174-182. http://doi.org/10.9770/jesi.2016.4.2(5)

Sultan, F., Urban, G., Shankar, V., \& Bart, I. (2002). Determinants and role of trust in e-business: a large-scale empirical study [Working Paper No 4282-02]. MIT Sloan School of Management, Cambridge, MA, USA. http://doi.org/10.2139/ssrn.380404

Sun, L.; Fuschi, D. L. (2015). Sustainable social entrepreneurship and motivation: a case study of two non-profit organisations in the UK, Entrepreneurship and Sustainability Issues 2(4): 179-187. http://doi.org/10.9770/jesi.2015.2.4(1)

Tang, Ying; Deng, Chao; Moro, Andrea. (2017). Firm-bank trusting relationship and discouraged borrowers, Review of Managerial Science 11(3): 519-541 Published: JUL 2017 
The International Journal

ISSN 2345-0282 (online) http://jssidoi.org/jesi/

2017 Volume 5 Number 1 (September)

http://doi.org/10.9770/jesi.2017.5.1(8)

Tumalavičius, V.; Nikolayevskyy, V.; Endziņš, A. (2017). Issues of the state and society security (Part II): management of control over individual criminal processes, Journal of Security and Sustainability Issues 6 (4): 605-618. http://doi.org/http://doi.org/10.9770/jssi.2017.6.4(6)

Tvaronavičienè, A.; Žemaitaitienè, G.; Bilevičienè, T. (2016). Ecosystem for sustainable entrepreneurship: towards smart public procurement review procedures, Entrepreneurship and Sustainability Issues 4(1): 39-52. http://doi.org/10.9770/jesi.2016.4.1(4)

Valentim, Lima; Vinicius, Igor. (2017). Confronting corruption in business: Trusted leadership, civic engagement, Management Learning 48(2): 245-248 Published: APR 2017 http://doi.org/10.1177/1350507616660425

Williamson, O.E. (1993). Calculativeness, trust, and economic organization, Journal of Law and Economics 36(1). https://doi.org/10.1086/467284

Yonk, Ryan M.; Hoffer, Sierra; Stein, Devin. (2017). Disincentives to business development on the Navajo Nation, Journal of developmental entrepreneurship 22 (2) Article Number: 1750012 Published: JUN 2017

Elena PETRENKO

ORCHID ID: 0000-0001-6892-2392

Nurlan ISKAKOV

ORCHID ID: 0000-0002-5103-2614

Oleg METSYK

ORCHID ID: 0000-0001-6842-9821

Tatyana KHASSANOVA

ORCHID ID: 0000-0002-1550-5592

Register for an ORCID ID:

https://orcid.org/register

Copyright (C) 2017 by author(s) and VsI Entrepreneurship and Sustainability Center

This work is licensed under the Creative Commons Attribution International License (CC BY).

http://creativecommons.org/licenses/by/4.0/

c) (i) Open Access

\} 